\title{
Posthuman Dijital Özne: Braidotti'nin Eleştirel İnsan Sonrasının Eleştirisi
}

\section{RABİA SAĞLAM ${ }^{1}$}

${ }^{1}$ Asst. Prof. Dr., Kocaeli University, Department of Public Law, Legal Philosophy and

Sociology of Law (Orcid ID: 0000-0002-3774-4332)

\section{Özet}

Bu makale Rosi Braidotti'nin ben ve öteki arasındaki içsel bağlantı temelinde insan ve teknolojiyi birbiriyle ilişkilendiren eleştirel posthümanist öznellik tasarısına odaklanıyor. Braidotti posthuman öznelliği, insan-olmayan ötekileri kapsayacak şekilde, içsel anlamıyla farklılaşmış göçebe bir oluş şeklinde tanımlar. Braidotti'nin tekno-bilimsel ilerlemeye dair eleştirel fakat aynı zamanda olumlayıı perspektifi, insanlığın geleceğinden toplumsal cinsiyet ve ırksal eşitsizliği tasfiye etmek adına, insan ve insan-olmayan öznelerin teknolojiye iliştirilmiş bir şekilde yeniden üretilebileceğine işaret eder. Buna karşın, ileri kapitalizmin şimdiki zamanında teknoloji dolayımındaki özneler arasında etik ilişkiler geliştirmenin mümkün olmadığını savunuyorum. Dahası, oluş etiğine dayalı insan sonrası özne inşası ileri kapitalizmdeki verili sosyo-ekonomik eşitlik nedeniyle gerçekleşemez. Braidotti'nin insan sonrası tasarısını Philip Dick'in "Human Is" öyküsüne uyarlayarak, posthuman özne öngörüsünün öyle ya da böyle insani bir kimlik varsayması gerektiğini göstermeye çalışıyorum. Bu düşünceye göre, günümüz tekno-aygıtlara bağlanan ve sanal ağlarla iletişim kuran insan sonrası dijital öznelerin, Dick'in öyküsüne atıfla, "yaşam değeri" yaratmaya ilişkin insani potansiyellerini gitgide yitirdiklerini öne sürüyorum. Ardından ileri kapitalizmde posthuman dijital öznenin ahvalini Deleuze'ün Denetim Toplumları Üzerine Postscript'ine referansla tartışıyorum. Nihayetinde, şirketlerin (piyasa güçlerinin) çıkarını teşvik ederken, insani kimliği ve kişilik haklarını metalaştıran posthuman hukukun bir örneği olarak kişisel verilerin korunmasına ilişkin normları kısaca inceliyorum.

Anahtar Kelimeler: insan sonrası, teknoloji, Rosi Braidotti, Philip Dick, posthuman hukuk 


\title{
Posthuman Digital Subject: The Critique of Braidotti's Critical Posthuman
}

\begin{abstract}
This article focuses on Rosi Braidotti's critical posthumanist project of subjectivity that relates human and technology on the basis of the internal connection between self and the other. Braidotti defines posthuman subjectivity as a nomadic being, which is internally differentiated, including the non-human others. Braidotti's critical but at same time affirmative perspective on techno-scientific progress points out that human and non-human subjects can be (re)produced in a way that entangled with technology in order to eliminate gender and racial inequality from humanity's future. Conversely, I argue that it is not possible to develop ethical relationships between technology-mediated subjects in the present time of advanced capitalism. And furthermore, the construction of posthuman subject resting on the ethics of becoming cannot be fulfilled because of the given socio-economic inequality in advanced capitalism. By adapting Braidotti's posthuman project to Philip Dick's story of "Human Is", I try to demonstrate that the prediction of posthuman subject must assume a humane identity, in one way or another. In accordance with this idea, I put forward that nowadays posthuman digital subjects, connecting with techno-devices and communicating via virtual networks gradually losing their humanitarian potential to be able to create a -with a reference to Dick's story- "value of life". Then I discuss the status of posthuman digital subject in advanced capitalism through a reference to Deleuze's Postscript on Societies of Control. Finally, I briefly examine the norms of personal data protection as an example of posthuman law, in which humanitarian identity and personal rights are commoditised, while the interests of companies (the forces of the market) are promoted.
\end{abstract}

Keywords: posthuman, technology, Rosi Braidotti, Philip Dick, posthuman law

Corresponding Author / Sorumlu Yazar

E-mail / E-posta
Manuscript Received / Gönderim Tarihi
Revised Manuscript Accepted / Kabul Tarihi
To Cite This Article / Kaynak Göster

To Cite This Article / Kaynak Göster

\author{
RABIA SAĞLAM \\ Kocaeli University, Department of Public Law, Legal \\ Philosophy and Sociology of Law \\ rabia_saglam@yahoo.com \\ January 25, 2021/ 25 Ocak 2021
}

March 23, 2021 / 23 Mart 2021

Sağlam, R. (2021). Posthuman Dijital Özne: Braidotti'nin Eleştirel İnsan Sonrasının Eleştirisi. ViraVerita E-Journal:

Interdisciplinary Encounters, Vol.13, 295-323. 


\section{Posthuman Dijital Özne: Braidotti'nin Eleştirel İnsan Sonrasının Eleştirisi}

\section{Giriş}

Bu makalede bilim ve teknolojiyle şekillenen öznenin, insan sonrası dönüşümü irdelenecektir. Modern hümanist hukukun özgür, özerk, hak ve kişilik sahibi öznesinin; diğer deyişle bedensel ve zihinsel potansiyelleri varsayılarak kurgulanan insanın doğası, tekno-bilimsel aygıt ve ağlarla ilişkiselliği geliştikçe değişti. Modern hümanist hukuk "insan sonrası insan”la karşı karşıya: Genetik mühendislik, nanoteknoloji, yapay zekâ mühendisliği ile bedeni/zihni (bio) ve yaşam alanı (zoe) radikal bir başkalaşım sürecinde yeniden tasarlanmakta olan yeni bir özne. Posthümanist felsefenin bedeni/zihni tekno-bilimsel aygıt ve ağlara iliştiren insan tasarımı, yeni öznellik biçimlerinden biridir. Bu makale postyapısalcı eleştirel yorum ışığında, hukukun önünde dikilen insan sonrası insan öznesinin ahvalini ele alıyor. Eleştirel yorum bu makalenin iddiasını ortaya koyarken başvurduğu yöntemdir. Eleştirel yorum, kuramların, farklı türden bilgilerin yalın tasvirine başvurmaz; söylenmişin aktarımından ziyade metinlerarası bir yolculukla araştırma nesnesinin dayanaklarını inşa eder. Rosi Braidotti'nin posthuman; insan sonrası insan öznesini açıklama şeması bu makalenin hem postyapısalcı yorumunun hem eleştirisinin çıkış noktasıdır. Braidotti'nin argümanları, günümüz ileri kapitalizminde posthuman öznellik biçimlerinden biri olduğunu ileri sürdüğüm dijital öznenin; tekno-bilimsel aygıt ve ağların dört tarafını çepeçevre sararak dijitalleştirdiği insan öznesinin tarifinde ve eleştirisinde başlıca referans kaynağıdır.

Makalenin amacı, hukuk felsefecilerini alışılageldik tartışma temalarından, kendini her akademik metinle yineleyen ana akım metot ve kavramlardan uzaklaştırarak "gelmekte olan", -hatta çoktan hukukun kapısına dayanmış- yeni özne oluş biçimlerini eleştirel bir bakışla izah etmektir. Posthuman özne, Deleuze tedrisatından geçmiş Braidotti'nin "oluş sürecindeki" "çok yüzlü" özne figürüne atıfla açıklanacaktır. Makalede, Braidotti'nin eleştirel posthümanist öngörüleri ve tezleri yapıbozumcu okuma stratejisiyle yeniden ele alınacaktır. Buna göre, Braidotti'nin farklı posthuman öznelerin karşılıklı, ilişkisel ve etik bir yaşam sürmelerine yönelik "proje"sinin, hâlihazırdaki ileri kapitalizm koşullarında gerçekleşmesinin mümkün olmadığı gösterilecektir. Yine de Braidotti'nin cinsiyetçilik, ırkçılık gibi sosyo-ekonomik eşitsizliklerin posthuman öznelerin yaşadığı ileri kapitalizmde ortadan kalkacağına ilişkin kuvvetli inancı, kurmaca bir dünyada yeniden düşünülebilir. Buna göre makalenin, insanın tekno-bilimsel aygıtlara bağlanarak, virtüel ağlarla iletişim kurarak dijitalleştiği günümüz ileri 
kapitalizm koşullarında insani ve yaşamsal değerlerini yitirdiği iddiası kurmaca bir metin üzerinden temellendirilecektir.

Kurmaca metin üzerinden makalenin iddiasının temellendirilmesi, ileri kapitalizmin, dijitalleşmenin ve teknolojik aygıtların insanın tinsel yanı üzerindeki yıkıcı etkilerini somutlaştırmayı amaçlamaktadır. Makale bağlamında yitirilen insani ve yaşamsal değerler, insanın sevgi temelinde ötekiyle birlikte yaşayabilmesine ve ötekinin gönlüne hitap eden bir dili konuşabilmesine ilişkin zihinsel/ruhsal potansiyelleri şeklinde tanımlanmıştır. Günümüz teknoloji dolayımındaki insan sonrası insanın (dijital öznelerin) ötekiyle birlikte yaşama değer katma potansiyelinin sönümlendiği ve ötekine yönelik değer yaratma becerisinin köreldiği argümanı, Max Scheler'in değer felsefesine başvurularak kısaca açıklanacaktır.

Bu makale ve yazarı, Braidotti'nin posthümanist yaşam modeline eleştirel mesafesini, romantik ya da nostaljik teknoloji karşıtlığını müdafaa ederek değil, en geniş anlamıyla bilim ve tekniğin insan-(lık)-ı başkalaştırmasının toplumsal ve ekonomik eşitsizliği perdelediği gerçeğini göz önünde bulundurarak koruyacaktır. Posthuman hukukun mahkûm edeceği fail yahut hak bahşedeceği birey, on dokuzuncu yüzyılın idealist, yirminci yüzyılın muhalif öznesi olamayacak kadar sibernetik dünyaya nüfuz etmiş; dijitalleşmiş bir insandır. İnsanın, insanlığına ilişkin değerleri, kitlesel bir dijitalleşmeyi teşvik eden tekno-kapitalizmin sanal doğasında (virtual nurture) erozyona uğramaktadır. İnsan, tek kişilik tekno-aygıtlarla iletişim kurarak, çevrimiçi kalarak denetim toplumlarına monte olabilen işbirlikçi 'ürün-özne' haline geldi. Makalenin temel varsayımı tekno-bilimsel "ilerlemenin" toplumsal cinsiyet, refah ve mülk eşitsizliklerini doğallaştırdığıdır. Ancak bu temel varsayım, başka bir makalemde (Sağlam, 2020) ayrıntılı bir şekilde tartışıldığından, burada kısaca ele alınacaktır.

Makalenin ilk bölümünde, Braidotti'nin eleştirel insan sonrası argümanları eşliğinde posthuman kavramı irdelenecektir. Makale, posthuman ya da posthümanizm üzerine yazılmış geniş felsefi literatürü betimlemek yerine, Braidotti'nin "eleştirelliği" ekseninde insan sonrası öznellik "proje"sini tartışacaktır. Braidotti'nin eleştirelliğinin temelsizliği ifşa edildikten sonra, makalenin iddiası -posthuman öznelerin insani değerlerini yitirdikleri- kurmaca metin üzerinden somutlaştırılacaktır. Braidotti'nin farklı insan sonrası öznellik biçimlerinin karşılıklı etik bir yaşamı sürdürebileceklerine ilişkin öngörüsünün şimdiki zamanda bir karşılığı yoktur. Ancak Braidotti'nin posthuman öznellik çeşitliliğinin yadırganmayıp tanındığı, teknolojik gelişmeyi olumlayan tasarısının kurmaca bir dünyada gerçekleşebileceğini söyleyebiliriz. Makalede kurmaca posthuman öznellik tasarısını Philip Dick'in "Human Is" öyküsünü 
inceleyerek temellendireceğim. Ayrıca Dick'in kurmaca metni, posthuman öznellik biçiminin ne anlama geldiğini, insanın dijitalleşerek ve dijitalleştirilerek neleri yitirdiği ve edindiğinin somutlaştırılması açısından da kayda değerdir. Makalenin ikinci bölümünde dijitalleşmenin tekno-bilimsel aygıtların insanın bedenini/zihnini işgal etmesi- insanlar arasındaki eşitsizliği ve adaletsizliği derinleştirerek görünmez kıldığı iddiasını, Deleuze'ün denetim toplumlarına ilişkin Postscript'ine başvurarak bir örnek üzerinden göstereceğim. Ardından hâlihazırda hukukun önünde bekleyen posthuman dijital öznenin ahvalini kişisel verilerin korunmasına ilişkin pozitif hukuk normları ekseninde kısaca tartışacağım.

\section{Human, Posthuman: İnsan, İnsan Sonrası}

\section{Posthuman Özne: Makine-Oluş}

Oxford sözlüğüne göre, 1970'lerde dolaşıma sokulan posthümanizm, insanın teknolojik araçlar ya da evrim süreciyle dönüştürülebilmesine, sınırlarının aşılmasına veya tasfiye edilebilmesine ilişkin düşünce; bu düşüncenin sanatsal, bilimsel ve felsefi pratiğe yansımasıdır. ' Posthümanizmi, insanın biyolojik canlılığının göstergesi bedeninin sınırlarının tekno-bilimsel araç, veri ve bilgiyle genişlemesi, ortaya çıkan yeni insan tipinin felsefi, siyasal, kültürel ve hukuki açıdan çeşitli yönleriyle irdelenmesi şeklinde tanımlayabiliriz. İnsan sonrası felsefi ve kültürel tartışmalar (Miah, 2007, s. 5 vd.) genel olarak, adına insan dediğimiz bedensel bütünlüğü nasıl tanımladığımızı sorunsallaştırmakla işe başlar, tekno-bilimsel "ilerleme"nin bildiğimiz insanı nasıl dönüştürdüğünü temalaştırarak devam eder. Insan her şeyden önce bilinci ya da zihinsel yetileri bedeninde cisimleşmiş bir canlıdır. Biyolojik evrim açısından bakıldığında, insan bedeni teknolojik yeniliklerle geri dönüşsüz, sonu gelmeyen bir “ilerleme” kaydetmiştir. İnsanı insan kılan vücut bulma halinin tekno-bilimsel aygıtlarla dönüşme sürecini ele alan farklı posthuman yaklaşımlarını iki başık altında toplayabiliriz: İnsanın tekno-bilimsel dönüşümünü endişe verici bulanlar ve umutla bağrına basanlar. Hayles'a göre insanın bu dönüşümü, teknolojiye düşman kesilen kıyamet habercilerinin düşündüğünün aksine, insanlığın sonunu hazırlamak anlamına gelmez. Posthuman, insanın değişmez kökenini varlık/yokluk, ilişkisellik/tesadüfîlik kavram kategorileriyle açıklayan kültürel şemaların virtüel teknolojiler ve yapay makinelerle içeriden dönüşmesidir (Hayles, 1999, s. 285). Akıllı makinelerin insan bedeniyle simbiyotik kardeşliğini vurgulayan iyimser posthuman düşüncesi, 
insanı "bireysel tercih ve failliği aracılığıyla iradesini ortaya koyan otonom varlık" varsayımı temelinde kurgulayan Avrupa felsefesinin nihayete erdiği görüşündedir. Sözgelimi Haraway'in posthuman siborg öznesine ve siyasetine biçtiği yapıcı rol, insan merkezli her türlü tahakküm ilişkilerini sekteye uğratacak güçtedir: "Siborg siyaseti, (...) Hayvan ile makinenin gayrı-meşru birleşmelerini sevinçle karşılayarak, gürültüde ısrar edip kirliliği savunur. Bunlar dili ve toplumsal cinsiyeti doğurduğu tasavvur edilen (...) 'Batı' kimliğinin, doğa ile kültürün, (...) köle ile efendinin, beden ile zihnin yapısını ve üretim tarzlarını yıkarak Erkek'i ve Kadın'ı ciddi bir sorunsal haline getiren eşleşmelerdir" (Haraway, 2006, s. 62).

Büyük varlık zincirinin üyesi insan türünün değişimini -siborg, android, sibernetik, robotik- "farklı" türlere sıçrama temelinde gerekçelendiren transhuman anlayışına da kısaca değinelim. Biyoteknoloji, nanoteknoloji, rejeneretif tıp -insan veya hayvan doku, hücre ve organlarının yeniden oluşturulması- mind uploading (zihnin ya da beynin taranıp bilgisayara yüklenmesi) gibi mevcut ve fütüristik çalışma alanları transhuman düşüncesinin muhtevasını oluşturur (Ferrando, 2013, s. 27). LaGrandeur'a göre transhuman, insan türünün ahlaken ve fiziksel açıdan gelişmesi, hatta ölümsüzleşmesi anlamına gelir (akt. Wennemann, 2016, s. 21). Bu anlamıyla transhuman, posthuman öznellik formlarından biridir.

Insan sonrası öznellik formlarını -dijital/trans-, makalenin iddiası bağlamında Deleuze terminolojisine referansla "makine-oluş"la tanımlayabiliriz. Makine-oluş, insanın ne olduğu üzerine felsefi argümanlar üretmek yerine bedenle ne yapılabilir sorusuna yanıt arar (Corda, 2017, s. 86). İnsanı, beden ve zihin ayrımına dayanarak açıklayan Kartezyen düşünce sisteminin raf ömrü dolmuştur artık. İnsan sonrası insan, bedeninden mütevellit bir makineoluş’tur. Deleuze'ün Nietzsche ve Spinoza okumasına göre insan bedeni, kendi tekilliğinde kendini düzenleyebilen, yaratıı bir şekilde kendini aktive edebilen bir özne oluş akışıdır (2017, s. 87). Gelişme sürecindeki beden, olmakta olan öznellik anlamına gelir. Insan merkezci yeknesak, tamamlanmış birey kurgusunu kökünden söken bu yeni posthuman öznellikte beden/zihin, başından beri gelişmekte olan süreçle düzenlenmektedir. Buna göre makineoluş, insanın bedensel (dolayısıyla zihinsel) yetilerinin dışsallaşması ve düşünen makinelerin insan kimliğine eklenmesidir (Zizek, 2013, s. 49). Makine-oluş sürecini olumlayan Zizek, yetilerin makinelere aktarıldığı ölçüde, insanın özgürleşeceğine ve öznelliğine temiz bir sayfa açabileceğine inanır. İnsan öznelliğinin geleceği, siber-insandır: İnsanın nöron sisteminin doğrudan bir bilgisayar ağına bağlanması (2013, s. 50). İnsan sonrası özne, dışsal nesnelere 
kendi ayırt edici vasıflarını aktardığı, diğer deyişle özne-insanlığının içini boşalttığı, ardından bu "dışsal mekanik" araçların veri akışına bedenini teslim ettiği ölçüde özgürleşir.

Braidotti de insanın makine-oluşunu yüceltir. Braidotti’ye göre makine-oluş, cinsiyetçi, ırkçı köken söylemine dört elle sarılan insan merkezci hümanist felsefenin insan kurgusunun yapısını bozup yeniden temellendirecek bir bakış açısıdır. Fakat Braidotti, ana akım posthümanist düşünürleri, tekno-kapitalizmin doğayı-evreni tahrip eden sonuçlarına aldırış etmemekle itham ederek eleştirel mesafesini korur. Braidotti'nin eleştirel mesafesinin suya sabuna dokunmayan muhtevasını bir sonraki başlıkta yapıbozumcu okuma stratejisiyle irdeleyeceğim. Şimdi kısaca Braidotti’nin insan sonrası özne tasarımına değinelim.

Braidotti, hümanist felsefenin insan anlayışını modern Avrupa'nın düşünsel mirasının temeline yerleştirir. Felsefi hümanizmin öznellik kurgusunu aynılık ve farklıık karşıtlığında eleştiren postyapısalcı kuramcıların, -Foucault-Deleuze-Derrida- görüşlerini bir yönüyle sürdüren Braidotti, (1) posthümanizm eleştirisinin nasıl bir öznellik kurgusuna -klasik insan merkezci hümanizm- yöneldiğini, (2) posthuman öznenin farklılı̆ının anlamını ve sınırlarını belirginleştirerek tartışır. Hümanist felsefe insan öznelliğini, “-den farklı olmak" üzerine inşa etmiştir. Buradaki farklılık, negatif yargıları dışlayan 'nötr' bir kategori değildir. Tam aksine, “den farkı olmak" öznelliğin belirli vasıflarını taşımamak, hiyerarşik olarak aşağıda olmak; “ötekilik" demektir. Öznellik "bilinçlilik", "evrensel rasyonalite” ve "kendini düzenleyen etik davranış"a eşittir ve "farklılı̆ı bunlarla örtüşecek şekilde tanımlayan" insan merkezci düşünceye göre ötekilik, "öznenin yansıtıcı muadili olarak olumsuz terimlerle tanımlanır" (Braidotti, 2017, s. 105). Evrensel hümanizmin kültürel yapısı ben ve öteki arasındaki karşıtlığı besleyip büyütür. Farklılık, hiyerarşik ben ve öteki ikiliğinde küçümseyici bir anlamda kullanılır. Braidotti insan merkezci hümanist öznellik kurgusunun bin bir yüzünü ifşa eder: Böylelikle bazı canlı varlıklar cinsiyetlendirilir, ırksal şeceresi tutulur, tür-dışı sayılır ve nihayet doğa-dışı addedilerek gözden çıkarılabilir bedenler haline getirilir (s.105).

Braidotti'ye göre, insan merkezci hümanist insan imgesi; Antik dünyada kendisine dil bahşedilmiş rasyonel hayvanın, İtalyan Rönesans'ında Leonardo da Vinci'nin Vitruvius Adam'ı (Vitruvian Man) ile ideal formunu kazanır. Vitruvius Adam’ın erkek bedeni, insanın kendini düzenleyebilen, biyolojik, söylemsel ve ahlaki kapasitesini imgeleştirir. Braidotti, erkek bedene tüm insan potansiyellerini sıkıştıran bu 'insan' figürünün, Hegel'den Husserl'e, Avrupa faşizminden evrensel kültürüne tek tip insan kurgusunun soy zincirini koruduğunu ve dayattığını ileri sürer. İnsan olmak erkekliğe ve Avrupa medeniyetine özgü iken ötekilik, "akıl- 
dışılık, ahlak-dışıık, kadınlık ve batılı olmama ile tanımlanır" (Braidotti, 2018, s. 25 vd.) Hümanizmin insan anlayışına göre, "hepimiz insanızdır ancak kimileri diğerlerine göre daha ölümlüdür" (Braidotti, 2013, s. 2).

Braidotti, insan merkezciliği erkek insanla tanımlayan Avrupa hümanist düşüncesinin anti-hümanist bir damara kan pompaladığını ifade ettikten sonra eleştirel insan sonrası perspektifini "Spinozacı Deleuze"ün argümanlarına yaslanarak açıklar. Braidotti’ye göre (2019a, s. 66) doğa-kültür sürekliliğinde insan, makine-oluşunun yanı sıra hayvan-oluşunu da "şimdide" eş zamanlı yaşamaktadır. Hümanist felsefenin ölümlü insanın doğayı karşısına alıp 'kültür'e sığınarak diğer canlılardan kendini özenle ayırma yöntemi, geçerliliğini kaybetmiştir. Diğer deyişle, insan sonrası süreçte tür anlamıyla antropos'a (anthropos) has öznellik ayrıcalığı sona ermiştir.i" Antropos'u diğer türler karşısında göklere çıkaran, doğal kişilik ve haklarla donatan hümanist anlayışın yerini çoklu yaşam formları alır. Çoklu yaşam formlarında insan, bedenin sınırlı doğasına hapsedilmez. Beden bilgiye dönüşür. Teknoloji tam burada devreye girer; androidler, siborglar, robotlar insan sonrası insanın, -tıpkı havyanlar, bitkiler gibi- aynı doğayı paylaştığı farklı türlerdir. Herkesin (insan) her şeyle (makine) bağlantı kurduğu çoklutürlerden mütevellit bir doğada, teknolojinin ve bilimin çığır açan nimetleri insanlığın bağrına basılır. Braidotti'ye göre, bu tür bir doğa yeni-Spinozacı materyalist kozmos tasarısıdır. "Türlerin ötesindeki" posthuman özneler, virtüel-gerçek bu ikinci doğada etik bir yaşamı sürdürebilir.

İkinci doğa, hümanist insanlığın, kanlı bıçaklı olduğu "ötekiler"le ve oluş sürecindeki yeni "başkaları"yla iç içe yaşayabileceği alternatif bir yaşam modelidir. Braidotti'nin ifadesiyle posthuman özneler, "ahlaki rasyonellik", doğuştan getirilen ya da toplumsallıkla edinilen evrensel ahlaki değerlere "yabancılaşmış", "çoklu-başkalarıyla açık uçlu, birbiriyle ilişkili, çoklucinsiyetli, türler-ötesi bir oluş akışıdır" (2018, s. 110). Öyle ya, insan merkezci hümanist felsefe, beyaz-erkek-sağlıklı bedenleri insan türüne aidiyetin; öznelliğin evrensel asli bileşeni kabul etmişti. İkinci doğa, teknoloji dolayımında yeniden biçimlenmiş insanımsı, insan-dışı, yarı-insan, yarı-otomatik organizma benzeri canlı/cansız türlerin çoklu yaşam biçimlerinin alanıdır. Alternatif yaşam modelinde, posthuman özneler "benliğin", "türün”, "ölümün” ve "kuramın" ötesinde "göçebe" bireylerdir. Braidotti'nin posthuman öznesi, "insan-olmayan failleri içeren bir montaj"dır (2018, s. 102). Teşbihte hata olmaz diyerek farklı posthuman öznelerin birlikte yaşam modelinin ne anlama geldiğini bir örnekle açıklayalım. On yedinci yüzyılda Edirne'ye bağlı Maraş köyü ahalisi, Bıyıklı Ali'nin hortladığını düşünüp hal çaresi için 
kadıya başvurur. Köylü, kadıya hayvanlarının öldüğünü, gece garip sesler duyduklarını söyleyip, suçu mezarında rahat uyuyamayıp köye musallat olan Bıyıklı Ali'ye atar. Müslümanların mezarından çıkarılıp yakılması caiz olmadığından Edirne Kadısı bir üst merciye başvurur. Nihayetinde bilirkişi ve tanıklar huzurunda mezar açılır, Bıyıklı Ali'nin cansız bedeni (hortlak) köye korku salmasın diye yakılır (Numanoğlu, 2018, s. 8; Kırgi, 2018). Braidotti'nin tasarısında hortlak Bıyıklı Ali, tıpkı siborg gibi, bir posthuman özne kabul edilebilir; insan sonrası insan, başka ötekilerle (insan-dışı yaşam formları) aynı çatı altında bir arada yaşayabilir.

İnsan merkezci hümanist felsefenin aşağıladığı, çoğu zaman ölüsünü ya da dirisini yaktığı bu başka ötekilerle insanlar, içli dışı bir ilişkisellik kurabilir. Özetleyelim: Braidotti'nin insan sonrası düşüncesi, insanın bu yeni başkalarıyla; teknolojik aygıtlara ve ağlara monte edilmiş doğal/yapay, canlı/cansız organizmalar ya da makinelerle karşılıklı, yakın ilişkisini olumlar.

\section{Eleştirel Insan Sonrası: Braidotti'nin Temelsiz Eleştirisi}

Braidotti'nin eleştirel insan sonrası tasarısı, hayvanların, makinelerin ve teknoloji dolayımındaki insanın birlikte etik bir yaşam sürdürmelerine dayanır:

Bir zamanlar insan merkezci ve hümanist erkek insanın "ötekileri" olarak bilinen bu cisimleşmiş insan-olmayan özne konumlarıyla, insan merkezcilik sonrası transversal bir yapısal bağlantının kabulü hepimizin işine yarayacaktır. Projenin etik kısmı, bu tekno-başkalarıyla yeni bir toplumsal ağ ve bağlantı biçimleri yaratmaya dairdir. Teknoloji dolayımındaki organizmalarla doğa-kültür sürekliliği içinde ne tür bağlar kurulabilir ve bu bağlar nasıl sürdürülebilir? Akrabalık ve etik hesap verilebilirlik, sadece insan-biçimli olmayan organik başkaları için değil, aynı zamanda teknolojinin dolayımında gezegenimizi paylaştı̆̆ımız patenti alınmış yeni yaratıklar için de yeniden tanımlanmalıdır (2018, s. 126).

Braidotti'nin çoklu-öznelerin ikinci doğada etik yaşamı mümkün kılabileceklerine ilişkin "proje"si, insan merkezci hümanist felsefenin tekno-kapitalizmle ele ele verip bireyi tüketime sevk eden, ırkçılığı, toplumsal cinsiyet eşitsizliğini tertip ederek doğallaştıran siyasetinin, kültürünün bir eleştirisidir: "Teknolojik başarılar ve bunların sağladığı zenginlik karşısında duyulan gurur, ileri teknolojilerimizin yarattığı muazzam çelişkiler ve toplumsal ve ahlaki eşitsizlik biçimlerini görmemize mâni olmamalıdır. Bilimsel tarafsızlık veya küreselleşme 
sayesinde tekrar alelacele inşa edilen pan-insani bağ hissi uğruna bunlara değinmemek sorgulanmalıdır" (2018, s. 58).

Braidotti'nin insan sonrası eleştirisinin temelsizliğini tek başlık altında irdeliyorum: Braidotti'nin posthuman oluş sürecine perspektivist bakışı, hararetli eleştirel söylemine karşın, erkek egemen insan merkezci hümanist kodları farklı bir tonda yineler. Eleştirimi, Braidotti'nin Mart 2019 yılında Harvard Üniversitesi Tasarım Enstitüsü öğrencilerine sunduğu "İnsan Sonrası Bilgi" başlıklı bildiri metni ekseninde temellendiriyorum. Braidotti'nin dijital ortamda erişime açık konuşma metni, genel düşünce çerçevesinin aktüel, derli toplu ve görsel özetini sunması nedeniyle önemlidir. Eleştirimin amacı, Braidotti'nin eleştiri nesnesiyle dönüp dolaşıp aynı masaya oturmakta sakınca görmeyen söyleminin tepkiselliğini; eleştirelliğinin temelsizliğini göstermektir.

Braidotti, adı geçen konuşmasına, posthümanist kuramlara eleştirel mesafesinin genel hatlarını çizerek başlar. Posthuman sürecini hayra ve şerre yoranları, süreci çeşitli sözcüklerle tanımlama girişimlerini müstehzi bir üslupla eleştirir. Ardından "biz" zamirini kullanarak hem posthuman sürecinin hem posthümanist kuramların karşısında nasıl bir eleştirel yol takip edeceğini sorunsallaştırır. "Biz" zamirinin evrenselliğe ya da rölativizme işaret etmediğini vurgular. "Biz", Deleuze'ün yöntemiyle, "çoklu temellendirilmiş perspektiflere" işaret eder. Braidotti, "biz"in bir ve aynı şey olmadığını söyledikten hemen sonra, "çoklu temellendirilmiş perspektifini" "insan sonrası ilişkisellikte (convergence) birlikteyiz" argümanıyla açıklar. İnsan, insan sonrası sürecin kuramsal, sosyal, siyasal, tekno-bilimsel, ekolojik etkilerinin faili, iştirakçisi, fayda sağlayanı ve tarafıdır. Braidotti insan sonrası ilişkiselliğin eş zamanlı etkilerine tanıklığımızı üç fotoğrafla anlatır. İlk fotoğrafta, bir robot gösterilir. Robotun "bizim" yararımıza pek çok işi üstlenmesi (hizmet, temizlik, bakım vb.) posthuman ilişkiselliğin iyicil boyutudur. İkincisi, Jennifer Gabrys'in "dijital atık" adlı, teknolojik atıkları başının üstünde taşıyan siyah bir çocuğu tema eden fotoğrafıdır. Braidotti, bu iki görsel imgeden yola çıkarak eleştirelliğini billurlaştırır ve dijital kapitalizmin devlerine Harvard Üniversitesinin kürsüsünden ateş püskürür: Küresel, kâr odaklı şirketler -Apple- bilgisayarlarını, uzak diyarlardaki bu sefil insanlara karın tokluğuna toksik maddelerle yaptırmakta ve söktürmektedir. Üçüncü fotoğraf ikincisinin devamıdır: Bir nehirde birikmiş atıkları gösteren "plastik çorba" adlı fotoğraf. Üç imge insan doğasının tükendiğinin, bir sona yaklaştığının kanıtıdır. Liberal değerleri ülkü edinmiş Fukuyama ve Habermas da antroposen'in izinden giderek insan doğasının ne'liğini, posthuman sürecinin etkilerini görselleştiren bu tür olgularla birlikte tartışır. Oysa Braidotti, 
bilişsel (cognitive) kapitalizm döneminde posthumanı, iklim değişikliği, çevre felaketleri, insan soyunun tükenişi gibi kötücül senaryolarla birlikte telakki etmenin etkili bir perspektif sunmadığını iddia eder. Nihayetinde "bizim" insan sonrasıyla yakınsallığımız da dikkate alınmalıdır. Braidotti'nin posthuman perspektivizmine göre, bilişsel kapitalizmle ya da insan sonrasıyla ilişkimiz, "bilimsel devrimin" ve "inanılmaz bir inkişaf döneminin" de göstergesidir. iii

Braidotti'nin Spinoza-Deleuze çizgisindeki "gerçekçi”, "içkin”, "monist", "yenimateryalist" eleştirel insan sonrası yaklaşımı, tekno-bilimsel ağı düzenleyen ve denetleyen küresel şirketlerin etkisini göz önünde bulundurur, hatta ileri kapitalizmi tam da bu nedenle geçmiş yüzyıla kıyasla çok daha iğrenç bulur. Braidotti, tekno-kapitalizmin ekolojik dengeyi bozduğunu, küresel iklim değişikliğine ve çevre felaketlerine yol açtığını sürekli vurgular, müstehzi eleştiri oklarını teknolojik aygıtların üretilmesi, kullanılması ve denetlenmesinde söz sahibi egemen devletlere ve şirketlere yöneltmekte sakınca görmez. Fakat ileri kapitalizmi eleştirmek adına on dokuzuncu ve yirminci yüzyılın Marksist-Leninist söz dağarcığına sığınan argümanları da "gerçekçiliğe" ve "sağduyuya" davet eder: Eleştirellik insan sonrasıyla karşılıklı ilişkiselliğimizi; oluş sürecindeki öznelliğimizi de hesaba katmalıdır. Braidotti'ye göre oluş sürecindeki öznelliğimiz şu anlama gelir: Bilim insanları, akademisyenler, dünyanın en iyi üniversitesindeki (Harvard) öğrenciler, ileri kapitalizmin ürettiği tekno-aygıtların "keyfini sürmeli"dir.

"Olağanüstü bilimsel teknolojik aygıtlar"la yakınsallığımızın insanlığın insanlık-dışı ayıplarına son vereceğine inanan Braidotti, insan sonrası projesini bu inanç üzerine temellendirir. Nihayetinde Leonardo da Vinci'nin erkek insan figürünü Avrupa felsefesinin, kültürünün ve eleştirisinin biricik evrensel insanlık örneği ilan etmiş hümanist özne kurgusu, Braidotti'nin feminist benliğine hitap etmez. Sözgelimi Braidotti’ye göre insan sonrası kadınoluş, fallus merkezci siyasi ve hukuki karar alma mekanizmasında "ötekiler"i (kendi dışındaki tüm canlıları) “-den değersiz olma” kategorisiyle tanımlayan tarihsel geçmişten kurtuluş reçetesidir. Braidotti insan sonrası kadın-oluşu, "kendi evinde" konumlandırarak tanımlar: "Bu haliyle, bir dişi kurdum ben, her yönde hücreleri çoğaltan bir besiciyim; bir kuluçka makinesiyim, yaşamsal ve ölümcül virüslerin taşıyıcısıyım; geleceğin üreticisi doğa anayım" (2018, s. 100). Braidotti'nin oluş sürecinde farklılaşmaya devam eden insan sonrası kadın özneyi, bedenin 'doğal' dişilik işlevini sahiplenerek "kuluçka makinesi”yle özdeşleştirmesi ileri kapitalizm eleştirisinin içini boşaltır. Ama nasıl? 
Erkek insanı sahiplenmiş hümanist felsefi mirası eleştiren Braidotti, çoklu-oluş sürecinin hiyerarşik ilişkileri altüst edeceğini öne sürer. "Mesafelenme stratejisi" adını verdiği "içkin eleştiri"si, "aşina olunan düşünme ve temsil biçimlerinin" "yaratıcı alternatifler" (2018, s. 109) lehine silinmesini öngörür. "Yaratıcı alternatiflerin" (tekno-bilimsel aygıtların) özneyi radikal bir biçimde yeniden konumlandıracağına inanan Braidotti'nin "mesafelenme stratejisi", hâlihazırda içinde bulunduğumuz ileri kapitalizm çağında, insanın gelişimini ve dönüşümünü verili bir gerçek kabul eder. Bu nedenle eleştiri, temellendirilmiş bir temele dayanmaz; radikal değil reaksiyonerdir. Reaksiyoner eleştiri, verili gerçekliği kabul etme, verili gerçekliğe ateş püskürme edimleri arasında şekillenir. Braidotti verili gerçekliği, arkasındaki iktidar odaklarına ve ürettiği yıkıcı sonuçlara ateş püskürmesine rağmen, normatif açıdan 'nötr' addeder. Braidotti, kültürü doğanın devamı kabul ettiğinde verili teknolojik “ilerleme”yi tüm sonuçlarıyla -ki bu sonuçlara eleştirel mesafesine rağmen- olumlar. Şöyle diyelim: Braidotti, kuluçka makinesine indirgenen dişil bedenin sürdürülebilir bir doğada daha dayanıklı yeni türler üretmek amacıyla genetik yapısının değiştirilmesine itiraz etmez. Daha doğrusu, insana müdahale etmenin yapaylığı ya da doğallığına ilişkin ikilik, dişil bedenin (nature) kuluçka makinesi (artificial/nurture) kabul edilmesiyle ortadan kalkar. Tasvir edilen ileri kapitalizmde, verili durum -teknoloji dolayımındaki insan öznesi- yerilmez. Bilakis Braidotti, "teknolojinin normatif olarak nötr" olduğunu sıklıkla vurgular (2018, s. 60). Kuluçka makinesi, tıpkı fotoğrafta gösterilen robot gibi, Braidotti açısından "insan sonrasının yaratıcı potansiyelinin" göstergesidir. Dolayısıyla Braidotti, insan sonrasındaki kadın-oluş biçimi olarak kuluçka makinesine teknolojik aygıtların maliki ya da zilyedi iktidar ağının her türlü müdahalesinin önünü açar. Braidotti'nin konuşma metnine dönerek eleştirel insan sonrasının eleştirisine devam edelim.

Braidotti'nin eleştirisi ileri kapitalizm sürecine ve sonuçlarına yöneliktir: (1) Bilişselbiogenetik kapitalizm ile medya ve bilgi teknolojileri yaşayan her şey üzerinde hak sahipliği iddiasındadır. (2) Günümüz sermayesi, yaşayan maddenin iç dinamiklerini, kendi kendini organize etme kapasitesini kâr kapısı haline getirmiştir. (3) Öyle ki bu yeni tür denetim toplumlarında, tekno-bilimsel iktidar ağı hem yaşam (bio) hem ölüm (necro) meleğidir. Braidotti eleştirel argümanlarını sıraladıktan sonra içinde yaşadığımız ileri kapitalizm koşullarını farklı bir perspektifle değerlendirmek gerektiğini belirtir. Özel ve kamusal silah endüstrisinin yaşamları sermayeleştirdiği, ölümlerin insansız hava araçlarıyla (drone) failsiz ve cezasız kılındığı bir sistemde, Braidotti'nin önerdiği farklı perspektif, "olağanüstü” tekno- 
aygıtları dolaşıma sokan, denetleyen iktidar ağıyla uzlaşmaya açıktır. Nitekim Braidotti, drone fotoğraflarını öğrencilere gösterirken Hollanda Askeri Akademisiyle birlikte çalıştığından bahseder. Braidotti'ye göre Hollanda Askeri Akademisinde çalışanlar drone'ların varlığından ziyadesiyle endişe duymaktadır. Illk olarak drone'lar askerlerin işini ellerinden almaktadır, ikincisi askerler insandır; öldürme fiilinin icrasında belirli davranış normlarına tabidirler, oysa drone'ların bir davranış kodu yoktur. Braidotti savaş makinelerinin doğal/politik iktidarın elinde yaşamı ve ölümü metalaştırdığını argümanlaştırıp sistemin aktörü bir ülkenin askerlerinin endişesini dile getirdiği anda eleştirel söylemini temelsizleştirir. "Olağanüstü" silah üreten (drone), ürettiği silahı başka ülkelere satan Çin ve ABD'den söz eden Braidotti, zenginliğine zenginlik katan Avrupa Birliği ülkelerinin ABD ve İsrail'den silahlı "MALE drone" ithal ettiğine hiç değinmez. Dahası, Avrupa Birliği ülkeleri (Almanya, Fransa, İtalya) 2013 yılından itibaren Avrupa'nın "stratejik özerkliğini", "askeri uçak endüstrisini" koruma amacıyla "eurodrone" üretme kararı almıştır. 2025 yılına kadar eurodrone'ların istihbarat, gözetleme, hedef tespiti ve keşif görevlerini dünyanın her yerinde yürütebilmesi, ayrıca silah da taşıyabilmesi öngörülmektedir (Postma, 2019, s. 15). NATO ve Avrupa Birliği üyesi Hollanda'nın 'insancıl' endişesini dile getiren Braidotti'nin püskürdüğü eleştirel ateş saman alevi gibi söner.

Braidotti'nin, Askeri Akademinin endişesini dile getirmesinin eleştirel düşüncesiyle tutarsızlığını göstermeye çalışmıyorum; posthuman özne perspektifinin eleştirdiği Vitruvius Adam'ı farklı bir üslupla yinelediğini iddia ediyorum. Fütursuzca insan öldüren savaş makinesinin varlığını askerlerin 'işimizi kaybedebiliriz', 'makinelerin öldürmeye ilişkin davranış kodları insanlar gibi değil' endişesini “insan sonrası bilgi” konuşmasında diline dolayan eleştirel söylem, tam da kaçındığı hümanist erkek insan modelini yeni bir yazım kılavuzluğu eşliğinde tekrar etmektedir. Öyle ya, savaş makinesi -drone- militarizmi meslek edinmiş askerlerin işini ellerinden alacaktır, öldürmeyi antropos'un ve human'ın birincil vazifesi gören klasik erkek insan figürünün yeryüzündeki varlık nedenini ortadan kaldıracaktır. Öldürmenin insancıl kodlara tabi olması gerektiğine yönelik endişe, insan merkezci hümanist söylemin mirasıdır. Silahlı drone'ların "MALE" adıyla "erkek insan" figürünün tüm çağrışımlarını bünyesinde toplaması bile bu cinsiyetçi mirasın -insan merkezci hümanist söylemin- sürekliliğine işaret eder. Nitekim artık erkek insanın, kendi türünü ve diğer canlıları öldürme iktidarı "MALE drone"ların, savaş makinelerinin eline geçmiştir. 
Özetleyelim: Braidotti'nin drone'ların varlığını sorunsallaştırmayıp insancıllığını ve insanın emek gücünü elinden almasını sorgulayan eleştirel tutumu Avrupalı, beyaz, erkek insanın insancıl 'endişe'sini posthuman öznenin 'eleştiri'si haline getirmektedir. Braidotti'nin eleştirelliğini ateş püskürme metaforuyla imgeleştirmekle hem reaksiyonerliğini hem eleştirdiği insan merkezci hümanist erkek öznenin imtiyazlı mirasını yinelediğini göstermeye çalıştım. Bundan sonraki başlıkta kurmaca bir metin üzerinden posthuman özne tasarısını irdeleyeceğim. Böylelikle Braidotti'nin keyfini sürmemiz gerektiğini salık veren tekno-bilimsel "yaratıcı alternatiflerin" oluş sürecindeki insan öznesine neler vaat ettiğini, çoklu-özne oluşların bir arada yaşamasının mümkün olup olmadığını yeniden değerlendirebiliriz: Braidotti'nin posthuman özneleri, insanlıklarını yitirmedikleri ölçüde etik bir yaşam sürebilir.

\section{Posthuman Insan Öznesi: Insan Olmak ya da Olmamak}

Braidotti'nin posthuman özne tasarısının örneğini Dick'in "Human Is" öyküsünü inceleyerek göstereceğim. Dick'in kurmaca metni Braidotti'nin öngörülerini ve tezlerini somutlaştırır. Dick'in öyküsünü üç argüman eşliğinde ele alıyorum: (1) Bedeni insan-olmayan öteki tarafından işgal edilmiş Lester, Braidotti'nin tasarladığı bir posthuman öznedir, (2) posthuman Lester'ın ileri kapitalizmin şimdiki zamanında bir karşılığı yoktur, (3) zira makine-oluş sürecindeki posthuman insan, insani değer yaratma potansiyellerini yitirmiştir.

Dick'in "Human Is" öyküsü ilk defa 1955 yılında Startling dergisinde yayımlanır. Öykü Jill'in gözyaşlarıyla açılır. Zira Jill'in, erkek kardeşinin oğlu Gus'ı bir süreliğine evde misafir etme arzusu beş yıldır evli olduğu kocası Lester tarafından hoş karşılanmaz. Jill bedbaht ve hınç doludur. Lester bilim insanıdır ve ordu için yeni bir zehir üzerinde çalışmaktadır. İki üç haftalığına Rexor IV gezegeninde bilimsel araştırma yürütmekle görevlendirilir. Jill, kocası seyahatten döner dönmez boşanmak ister. Jill'e göre kocası sabahtan akşama kadar iş düşünen, hırslı, insafsız, soğuk nevaledir; "insanlıktan çıkmıştır" (inhuman) (Dick, 1955, s. 69).

Ne var ki işkolik, görev aşığı Lester'ın Rexor IV'ten Terra gezegenine dönüşü muhteşem olur. İnsanlık-dışılığı insanlığa, hoyrat erkekliği gönül adamlığına dönüşmüştür. "Acımasız" (cruel) ve "nemrut" (ruthless) Lester'dan eser kalmadığını gören Jill, beş yıldır alışık olduğu ruhun ve dilin farklılığına inanamaz önce. Hiç duymadığı kelimeler, metaforlar, deyimler dökülür ağzından Lester'ın (s. 70). Bilimsel/rasyonel, evet/hayır mantığıyla iş gören, her nesneyi doğru adıyla sınıflandıran erkek insan buharlaşmıştır. Bedeni ileri kapitalizmin hüküm 
sürdüğü Terra'nın doğasında 'aynı' kalmış, fakat ruhu ve dili yüzyıllar öncesinin eski Terra'sının insanlığına geri dönmüştür: Geçiştirdiği öğünlerini şimdi tadına vara vara yer, güler, şakalaşır, mütemadi bir nezaket çöker haline tavrına. Vakti zamanında romantizmi akıldışı bulan Lester enikonu romantik bir erkek olmuştur. Öyle ki yeğen Gus'ı evde misafir etmeyi bile canı gönülden ister (s. 71). Peki, ama Lester'a Rexor IV gezegeninde ne olmuştur? Jill'e göre insanlıktan nasibini almamış tekno-bilim insanı Lester, yaşam sevinciyle dolup taşan bir insan haline nasıl gelmiştir?

Rexor gezegeninde hayat yok olmaya yüz tutmuştur. Insan-olmayan kadim ırk Rexoryalılar elden ayaktan düşmüş, bedenleri çelimsizleşmiştir. Pek çoğu başka gezegenlere göç etmeye teşebbüs ederken ölmüştür. Nihayetinde bir çözüm bulur Rexoryalılar: Zayıf bedenlerini kuvvetli bedenlere zerk edebilecekleri, sağlıklı bedenlerin psişik hususiyetlerini pasifize ederek kendileri kalmaya devam edebilecekleri bir sistem. Girdikleri bedenin psişik (zihinsel/ruhani) içeriklerini kaldırıp -bir tür askıya alma- anında kendi ikame içeriklerini enjekte ederler (s. 72). Başka bir deyişle, işgal ettikleri bedendeki kayıtlı bilgiyi başka bir yere saklayıp, kendi ruhlarını organizmaya yerleştirebilecekleri bir 'hayatta kalma' teknolojisi icat etmişlerdir. Böylelikle Rexoryalılar başkasının bedeninde yaşamlarını sürdürebilirler. Eski Terralı insanlara dair her türlü kitabı okuyarak, onların dilini öğrenerek yeni bedenlerine adapte olurlar. Fakat insanlara dair okudukları kitaplar, konuştukları dil, eski yüzyılın Terralılarına aittir (s. 73). Dolayısıyla insan-olmayan Rexoryalı öteki, insan kimliğinin insani (psişik) kodunu Lester'ın bedenine kaydetmiştir. Bir bakıma Jill'in insanlıktan çıkmış (inhuman) kocasına, bedenini işgal ederek insanlık bahşeder Rexoryalı öteki. Tekno-bilimsel ilerlemeyi rehber edinmiş Lester, Rexoryalı öteki ile insanileşir. Lester’ın insanlıktan nasibini almamış bedeni, Rexoryalı bedensiz bir ruhun alternatif yaşam alanı; ikinci doğası olur.

Braidotti posthuman öznenin bedeninin yahut bedenleşmesinin biyolojik ya da sosyolojik bir kategori olmadığının altını çizer. Öznenin bedeni fiziksel, sembolik ve sosyolojik olanın kesişme noktasıdır. Beden, insan öznelliğini temellendiren, yapılandıran sınıf, ırk, etnisite, toplumsal cinsiyet, yaş, engellilik, cinsiyet gibi kimlik değişkenlerini aşma kapasitesinin de başladığı yerdir (2017, s. 38). Braidotti'nin insan sonrası öznesi, insan ve insan-olmayan faillerle karşılıklı ilişkiler kuran, maddi bakımdan iliştirilmiş, çok yüzlü, göçebe bir kendiliktir (2018, s. 221). Braidotti'nin tasarladığı doğada posthuman insan özneleri, bedenlerinin sınırlarını aştıklarında insanileşecektir; en azından toplumsal cinsiyet eşitsizliği ve ırkçılık posthuman öznelerin ajandalarından silinecektir (2018, s. 120). Bu anlamda bedenin sınırlarını 
aşarak Rexoryalı ötekiyle yakınsal bir ilişki kuran Lester Herrick, Braidotti’nin tasarladığı çokluoluş örneği bir posthuman öznedir. O halde Lester'in, bedeninde cisimleşmiş öteki ile yekvücut oluşuna posthuman öznellik biçimi diyebiliriz.

Lester'ın çoklu-oluşunu -Rexoryalı öteki tarafından ele geçirilen bedenini- Terralı yetkililer onaylamaz. Lester Herrick insan değil 'şey'dir ve Rexoryalı zihni/ruhu vibro-ışınla (vibro-ray) imha edilmelidir (s. 73). Fakat Terra gezegeninde uygulanan bir hukuk vardır. 'Şey' Terralı bir insanın bedenindedir ve Lester'ın zihninin/ruhunun yok edilmesine hukuk karar vermelidir. Öyleyse mahkemede Lester'in bedenine musallat, zihnine ikame 'şey'in casus olduğu kanıtlanmalıdır. iv Ancak başka 'şey'in tek tanığı Jill, kocasının insanlığında ısrar eder (s. 74). Lester’ın değiştiği; Braidotti'nin deyişiyle, başka bir ötekiyle bedeninin karşılıklı bir ilişkisellik kurduğu suçlamasını reddeder. Jill, yeni posthuman Lester Herrick'le; eski Terralı insanların diline ve ruhuna sahip Rexoryalı ötekiyle birlikte yaşamak istemektedir. Zira Rexoryalı öteki, Jill’in arayıp da bulamadığı bir 'insanlığı' Lester'a yüklemiştir.

Dick'ten yaklaşık kırk yıl önce Max Scheler, teknolojinin insanın tinsel yanı üzerindeki yıkıcı etkilerine dikkat çekmişti. Scheler'e göre, hayatı geliştirip zenginleştiren teknolojik araçlara canlı organizma değeri veren insan, insanlık değerlerini altüst etmiştir. Tekno-bilimsel dünya görüşü insanın ve hayatın gelişmesine hizmet etmeyi bırakıp, "'sonsuz ilerleyişi' bütün yaşamsal faaliyetin asıl 'amacı'” haline getirmiştir (Scheler, 2015, s. 222). İnsanın insanlıktan çıkmasının nedeni "mekanik medeniyet"in araçlarının kutsallaştırılmasıdır (s. 225). İnsan, yaşamın ta kendisinin emrine amade olması gereken tekniğin kulu kölesi olmuştur. Biyolojik evrim, mekanik evrimle yolundan şaşmıştır. Hayata içkin pek çok değer, Scheler'in ifadesiyle "yaşam değeri", makineleşmiştir:

Modern medeniyetin gelişmesiyle doğa (hükmetmek için insanın bir makineye indirgendiği doğa) ve nesneler, insanın efendisi ve tanrısı haline gelmiş ve makine hayata hükmetmeye başlamıştır. Nesneler, her geçen gün sağlamlık, zekâ, ölçü ve güzellik bakımından gelişme gösteriyor- onları yaratan insan ise giderek kendi makinesinde bir çark haline geliyor (2015, s. 224).

Scheler'e göre insan, ticaretin, faydacı ahlakın, sanayi kapitalizminin ifadesi mekanik medeniyete ait "hesapçı zihin" "her yönde engelsiz iletişim kurma" arzusu, "güvenlik", "her şartın hesap edilebilirliği” gibi ahlaki değerleri baş tacı etmiştir. Dahası Scheler, Nietzsche'ye atıfla, ressentiment fenomeninin göstergesi modern hümaniteryanizmin ya da evrensel insanlık sevgisinin bu tür değerleri beslediğini ileri sürer. Scheler'e göre soyut insanlık 
sevgisinin altında bastırılmış bir nefret duygusu yatar. Innsanlık sevgisi insan doğasının en aşağı, hayvani özelliklerine yönelmiştir (s. 146). Oysa somut ve dolaysız sevgi değerini temel alan bir yaşamda insan, pozitif değeri kendiliğinden ve doğrudan olumlar; hayatın kendisi tıpkı insan gibi orijinal bir fenomendir (s. 144, 205). Insan, cansız dünyanın canlı efendisi ve yaratılıştan sahibidir. Buna karşın modern hümanizm ve mekanik medeniyet insanın kendi değerini, cansız dünyaya uyarlamasıyla elde edeceği kazançlara ve faydalı olma kapasitesine bağlar (s. 202203). Bu tür değerleri takip eden insanın, değer yanılsamasıyla gözü kör gönlü kor olmuştur. Ne insanın ne yaşamın kendiliğinden bir değeri vardır artık.

Lester, Rexoryalı öteki ile ilişkiselliğinden önce bir değer yanılsaması içindedir; teknobilimsel dünya görüşünün, mekanik aklın bir dişlisi gibi düşünüp davranır. Yaşamın kendiliğinden bir değeri yoktur Lester için; canlı/cansız nesneler tekniğin ve bilimin faydalı araçlarıdır yalnızca. Karısı Jill’le iletişiminde bile Lester, insani değil mekanik bir dil kullanır. Değer yanılsaması Jill'le ilişkisinin her alanına sirayet eder. Öyle ki Jill'in "gudubet adam" (hideous) serzenişine, "değer yargısı, hiçbir olgusal karşılığı yok (...) sadece bir fikir, duygu ifadesinden başka bir şey değil” şeklinde karşıık verir (s. 67). Lester’ın pozitif bir değeri koşulsuz sevme, kendini ötekine adama, öteki için kendi konforundan vazgeçebilmegerçekleştirmeye ilişkin zihinsel/ruhsal potansiyelleri sönümlenmiştir. ${ }^{\vee}$ Tekniğin ve bilimin, Scheler'in ifadesiyle "kansız, duygusuz, aşksız ve nefretsiz" bir yığına çevirdiği, insani değerlerini yitirmiş Lester’ın insanlığını, Rexoryalı başka bir öteki geri getirir. Lester değer yaratan insanlığını, başka bir ötekine bedeninde yer açtığında kazanır. O halde insanın insani vasfı ya da ileri kapitalizmde insanın yitirdiği insanlık nedir sorusunun yanıtı, bedenin gönüllere hitap eden bir dilin ve yaşam değerinin taşıyıcısı olmasıdır.

Posthuman Lester, yaşama değer kattığı; insani potansiyellerini Jill'le ilişkisine yansıtabildiği ölçüde etik bir yaşamı mümkün kılar. Posthuman Lester'ın yaşama kattığı insani değer Jill'i yeniden hayata bağlar. Dolayısıyla Braidotti'nin bedenin sınırlılıklarını aşan çokluoluş sürecindeki insan sonrası insan projesi, yaşam değerini gerçekleştirmeye dönük posthuman Lester özneleri varsayar. Ne ki insani kimlik kazanan posthuman Lester’ın "bizim" gerçekliğimizde; içinden geçtiğimiz zamanda bir karşılığı yoktur. Ötekine yönelik insani değerle dolup taşan kurmaca metindeki posthuman Lester'ın ileri kapitalizmin gerçek dünyasında bir karşılığı olsaydı, Braidotti'nin iyimser alternatif yaşam modeli etik açıdan olumlanabilirdi. Ancak tekno-bilimsel "ilerleme", posthuman özneleri mekanik düşünme ve eyleme süreçlerinden kurtaran insani değerler sunmaktan çok uzaktır. Teknolojik aygıt ve sanal 
iletişim ağları insan sonrası insan öznesini insanileştirmez, aksine insanlığını askıya alır. Akıllı telefonlar, algoritmatik hesaplarla oluşturulmuş sanal ağlar insanın bedenini işgal edip, tinsel yanını; insanlığını ıskartaya çıkarmaktadır. İleri kapitalizmin "biz"i belirlediği verili gerçeklik, Braidotti'nin projesinin aksine, "insanlıktan çıkmış" -tekno-bilim insanı Lester gibi- öznelerin tesis ettiği bir yaşam modelidir.

Makalenin iddiasını hatırlatıp birinci bölümü sonuca bağlayalım: Mevcut ileri kapitalizm koşullarında bilim ve teknolojinin herkes için hazır ve nazır edilmesi, ulaşılabilir kılınması yeni bir tür insan öznesi yaratmıştır. Bedeni teknolojik aygıtlarla, bilimsel verilerle bütünleştirilerek üretilen bu yeni tür insan öznesi, insanlığın geçmiş yüz karası suçlarını -cinsiyet eşitsizliği, ırkçılık vb.- gelecekte tekerrür ettirmeyecek ahlaki bir donanımdan yoksundur. Zira posthuman insan öznesi, teknolojiye temas ettikçe yaşamsal değerler şirazesi kayar. Öyleyse Braidotti'nin öznelerin farklılıklarının tanındığı barışçı posthuman durumu, şimdiki zaman kipindeki bir gerçeklikte etik açıdan inşa edilemez. Bundan sonraki bölümde, makalenin teknokapitalizmin toplumsal ve ekonomik eşitsizlikleri görünmez kıldığı iddiasını dijitalleşen özne temelinde kısaca açıklayıp, hukukun dijital özneyle ilişkisini tartışacağım.

\section{Dijital Özne ve Posthuman Hukuk}

\section{Dijital Özne, Dijitalleşen Insan 'Doğa'sı: Denetim Toplumu}

Braidotti'ye göre, "insan sonrası şimdiyi, hem olmayı bıraktığımız şeyin kaydı (aktüel edimsel) hem oluş sürecinde bulunduğumuz şeyin tohumu (virtüel) olarak düşünmemiz" gerekir. Oluş sürecinde insanın şimdisi "karmaşıktır." Braidotti, oluş sürecindeki insanın şimdisini "geçmişteki gelecek" şeklinde tanımlar. "Geçmişteki gelecek", daima oluş sürecindeki göçebe özne olarak insanın, şimdiye dair kafa yorduğunda bir yandan mevcut koşullarla "yüzleşmesi", diğer yandan bu koşulları "aşması" anlamına gelir (2019b, s. 57). 'Bizim insan sonrasıyla ilişkiselliğimiz' derken Braidotti, tam da posthuman insan öznesinin hem geçmişteki insanlığına dair vasıfların hem gelecekteki makine-oluşuna ait unsurların şimdide buluştuğunu ifade eder. Bu başlık altında posthuman dijital özneyi, bedeni (maddi varlığı) ve zihni (manevi varlığı) makineleşen; teknik aygıtlarla iletişim, sanal ağlarla bağlantı kuran yeni bir insan-oluş şeklinde tanımlıyorum. Braidotti'nin ifadesiyle, "bizim" hem yüzleştiğimiz hem aşmamız gereken mevcut koşullar ya da şimdiki zamanımız, denetim toplumlarıdır: İnsanın 
maddi/manevi varlığının ürünleştiği dijitalleşme sürecidir. İnsan sonrasının şimdisinde tecrübe ettiğimiz, insanın dijitalliği (bio) ve dijitalleşen doğasıdır (zoe). Hukukun hâlihazırda önünde bekleyen özne, posthuman dijital öznedir.

Hukuk, insanı, akıllı telefon, sosyal medya ya da çevrimiçi arama motorları gibi insanolmayan diğer 'şey'lerle dijital bağlantısı vasıtasıyla kimliklendirdiğinde özneyi bedensel bütünlüğünden ayırarak mülkiyet konusu bir veri haline getirir (Käll, 2017, s. 1156 vd.). Dijital özneyi, hukuk önünde hak ve kişilik sahibi insanın, insanlığına atfedilen değerleri yitirmesi, bir ürün ya da veri haline gelmesi anlamında kullanıyorum. Öznenin çevrimiçi pazarda bir 'ürün' haline gelmesi ile insani kimliğinin dijitalleşmesi içinden geçtiğimiz ileri kapitalizm koşullarında vuku bulur. Bir sonraki başlıkta ileri kapitalizm koşullarında posthuman hukukun insanın kişilik statüsünü nasıl metalaştırdığına değineceğim. Fakat öncelikle Deleuze'ün argümanlarına dayanarak ileri kapitalizmde öznenin ürünleşme sürecini açıklayalım.

Deleuze'ün 1990 yılında yazdığı, 1992 yılında İngilizce yayımlanan denetim toplumlarına ilişkin Postscript'ti, bir bakıma dijital teknolojinin tarihini, mantığını ve izlencesini resmeder. Deleuze, Foucault'nun on sekizinci ve on dokuzuncu yüzyıl disiplin toplumlarına özgü bazı saptamalarının yirminci yüzyılda değiştiğini ileri sürer. Disiplin toplumları, kendine has yasalarla işleyen, okul, aile, hapishane, hastane, fabrika gibi kapalı alanlarda tek kişilik yaşamlara odaklanır. Egemenlik toplumlarında üretimi vergilendirmek, ölüm üzerine hüküm vermek asılken, disiplin toplumlarında üretimi organize etmek, yaşamı yönetmek birincil amaçtır. Deleuze'e göre, disiplin toplumlarında adı geçen kapalı kurumlar genel bir kriz içindedir ve reform söylemi kriz yönetiminin devası olamaz. Geleceğimiz, kapalı sistemde yürütülen modası geçmiş disipline etme standartlarından ziyade, "ultra-hızlı yüzergezer denetim biçimleri”ne ev sahipliği yapmaktadır. Tam da bu nedenle denetim toplumlarının dili sayısal, mantığı geometriktir; farklı denetim mekanizmaları bağlı değişkenlerle iş görür. Sözgelimi disipline edici eğitim kurumlarında bireyler genel kalıplarla yoğrulur, oysa denetim mekanizmasında bireyler bölünmüştür; zamansal ve çevresel koşullara uyum göstererek şekil değiştirirler. Denetim toplumlarında bireyler, kitleler, numuneler, veriler, piyasalar, bankalar haline gelmiştir ve bilgiye erişimin şifrelerle kabul veya reddedildiği bir şebeke içinde mütemadiyen sörf yapmaktadırlar (Deleuze, 1992, s. 3-7).

Deleuze, denetim toplumunda geçmiş yüzyılın sanayi kapitalizminin de mutasyona uğradığını vurgular. Üretime dönük kapitalizm, üretimi Üçüncü Dünya ülkelerine bırakmıştır artık. Hizmet satmaya dönük bir ürün kapitalizmidir bu; satılmak ve pazarlanmak istenen 
ürünün küresel serbest dolaşımı. Deleuze, kapitalizmin dağılmışlığına rağmen disiplin toplumlarından kalma bir toplumsal gerçeği koruyup sürdürdüğünü ifade eder: Denetim toplumlarında kapitalizm, insanlığın, borçlanmak için çok yoksul, cezaevine kapatılmak için çok kalabalık dörtte üçünün sefaletini değişmez veri olarak tutar. Deleuze, dört bir yana dağılmış kapitalizmin insanlığın sefaletinden yanalığını deşifre ettikten sonra eleştirisine direniş mecrası açar: "Korkuya ya da umuda gerek yok, yeni silahlar arayalım yeter" (1992, s. 4).

Deleuze'ün tasvir ettiği denetim toplumları dijital öznelerin yaşam alanıdır aslında. İnsanın tekno-bilimsel aygıtlarla her türlü bağlantısı ve iletişimi dijital öznenin kimliğinin bileşenidir. Dijital özne denetim toplumunda, Deleuze'ün ifadesiyle, "kodlanmış bir figürdür"; teknolojik aygıtlarla ve sanal ağlarla pazarlanabilen bir ürün. İleri kapitalizm, bölünmüş özneyi tek bir çatı altında -dijitalleşen doğa-, hem sayısal bir veri hem yeni koşullara uyum gösteren bir tüketici haline getirmiştir. Diğer deyişle bireyler, dijital dünyada herhangi bir malın ya da hizmetin "alıcısı" oldukları anda, kapitalist denetim toplumu alıcıyı, pazarlanacak ya da satılacak yeni ürünün parçası kılar. Dolayısıyla özne tekno-aygıtlarla doğrudan ya da dolaylı bir ilişkisellik kurduğunda maddi/manevi varlığını düzenleyerek şekillendiren iktidarın denetimine açar. Teknolojik aygıtlara bağlanma, -bilgisayar, cep telefonu, internet ağı-, ulusal ve küresel sermayenin insanları şekillendirerek veri haline getirdiği bir pazarlama motifidir. Braidotti'nin inandığının aksine bu tekno-kapitalizm, eşitsizliği (cinsiyet, ırk vb.) ortadan kaldırmak şöyle dursun, dijital özneler arasındaki gerçek eşitsizliği perdeleyerek görünmez kılmaktadır. Zira tekno-aygıtlara ve sosyal ağlara herkesin her yerde ulaşabildiği denetim toplumlarında görünüşte alan da veren de memnundur. Tekno-bilimsel aygıtları edinebilirlik, sanal ağlara erişebilirlik, insanın borçlu, insanlığın sefil yaşamını örtbas eder. Ileri kapitalizminin dijital özneleri borçlandırarak verili eşitsizliği ve adaletsizliği nasıl sürdürdüğünü örnekle açıklayalım.

Carthy O’Neil, Matematiksel Imha Silahları adlı kitabında, kapitalizm kavramını kullanmadan, teknolojik aygıtlarla etkileşime giren insanların -dijital öznelerin-, bu aygıtları üreten, kodlaştıran, pazarlayan, yayan, kullanan, dağıtan devlet ve özel şirketler arasındaki örgütlü iş birliğini deşifre eder. Amerika Birleşik Devletleri’nde Phoenix Üniversitesinin çevrimiçi reklamları kullanarak yoksul, siyah, kırılgan üniversite öğrenci adaylarını potansiyel müşteriye dönüştürmesi, ileri kapitalizmin borçlandırma taktiği, sefaleti kalıcılaştırma yöntemidir. Adı geçen üniversitenin öğrenci/müşteri kazanma stratejisi gayet basittir: Yoksul, geçmişinde duygusal travma vakası olan, fiziksel/manevi tacize uğramış, uyuşturucu/alkol tedavisi görmüş, gelecekten umudunu kesmiş, yoksul mahallelerde yaşayan gençlerin 
çaresizliklerini suistimal etmek. Öğrenci adaylarının internetteki sörflerinden, resmi kurumlardan, sosyal medya hesaplarından, telefon görüşmelerinden edindikleri verileri -sağlık bilgileri, yaşadıkları yerler, potansiyelleri, arzuları, düşleri, niyetleri, kaygıları- bilgisayar programlarına yükleyip modeller, örüntüler oluşturulur. Ardından adayın tercihine hitap eden bir dil ve içerik yaratılarak çevrimiçi reklamlarla Phoenix Üniversitesi göze sokulur. "Üniversite Google reklamlarına 50 milyon dolardan fazla para harcayarak, 2004-2014 yılları arasında ABD'deki üniversite öğrencilerinin yüzde 11 'ini" ayartmayı başarır. "Diploma imalathanesine dönüşen üniversitenin sloganı, yoksul insanları üst pozisyonlara çıkarmaktır. Manipülasyona aldanıp Phoenix Üniversitesini 'tercih' eden öğrenciler devletten aldıkları krediler nedeniyle borçlanarak mezun olur. Pek tabi diplomaları borçlarını ödeyebilecek bir iş imkânı sunmaz" (O’Neil, 2020, s. 82). Müşteri öğrencilerin borçlarına; hiç bitmeyen sefaletlerine karşın Phoenix Üniversitesinin ana şirketi Apollo Eğitim Grubu'nun CEO'su G. W. Cappelli 2011 yılında 25,1 milyar dolar kazanmıştır (2020, s. 93).

Bilgisayar programları (sosyal medya, e-ticaret vb.) -teknolojik aygıtlar- algoritma hesabına dayanarak "insanlığın dörtte üçünü" sefilliğe mahkûm etme hizmetini ürünleştirir. Tekno-bilimsel "ilerleme”, mevcut insan sonrası insanın -dijital öznelerin- kişisel verilerine birkaç saniyede erişebilmekte, bu verileri petabaytlara yükleyebilmekte, ardından değer, arzu, tercih profili çıkararak bireyleri pazarlanan ürünün pazarlayıcısı, dolayısıyla parçası haline getirmektedir. Başka bir ifadeyle söylersek, özne dijitalleştikçe ürünleşmekte, ürün haline geldikçe denetlenmekte, denetlendikçe kalıcı bir eşitsizliğin hüküm sürdüğü ikinci bir doğa; dijitalleşen bir zoe yaratmaktadır. Şirketlerin ve devletlerin kâr elde etmeye dönük kanaatlerini koda çevirdikleri dijitalleşmiş yaşam alanında -insan sonrasının şimdisinde- Braidotti'nin sürdürülebilir etik yaşam tasarısının somutlaşması mümkün değildir. Zira toplumsal ve ekonomik eşitsizliğin sürdüğü ileri kapitalizmde, teknoloji dolayımındaki farklı posthuman özneler arasında etik ilişkiler değil, hiyerarşik, bölünmüş ve manipülatif güç ilişkileri hüküm sürer. Peki, hâlihazırdaki ileri kapitalizmde hukukun işlevi nedir? Soruyu şöyle soralım: Hukuk, karşısına dikilen dijital öznelere nasıl seslenmektedir? 


\section{Posthuman Hukuk: Kişilik Hakkının Metalaşması}

Hukukun dijitalleşen öznelere hitabı, kişisel verilerin korunmasına yönelik yasal düzenlenmelerle başlar, unutulma hakkı gibi yeni hak kategorilerinin tanınmasıyla devam eder. Hukuk, çevrimiçi ağlarla bağlantı kurarak sanal platformlarda cisimleşen insanın maddi/manevi varlığını güvence altına alabilmek için gerçek kişiyi, 'dijital kişilik' formunda yeniden tasarlar. Kişisel Verilerin Korunması Kanununda, gerçek kişi insandır. Hukuken korunmaya değer görülen, insanın münferit kimlik ya da kişilik vasıflarıdır. Bu başlıkta kısaca, dijital platformlarda hukukun insan öznesinin maddi/manevi varlığını korumak adına, bir 'dijital kişilik' varsayması, varsayılan bu dijital kişilik üzerinden insanın kişilik hakkının metalaşması tema edilecektir. Böylelikle posthuman hukukun, (1) kişisel verilerin korunması hakkıyla dijital özne -dijital kişilik- inşa ettiği (2) kişilik hakkını ekonomik bir değere indirgediği ve nihayetinde (3) yukarıda açıklandığı gibi, insanı ürünleştirdiği gösterilecektir.

2010 yılında özel hayatın gizliliği ve korunmasını düzenleyen Anayasa m. 20/3’e, "herkes kendisiyle ilgili kişisel verilerin korunmasını isteyebilir. Bu hak; kişinin kendisiyle ilgili kişisel veriler hakkında bilgilendirilme, bu verilere erişme, bunların düzeltilmesini veya silinmesini talep etme ve amaçları doğrultusunda kullanılıp kullanılmadığını öğrenmeyi de kapsar. Kişisel veriler, ancak kanunda öngörülen hallerde veya kişinin açık rızasıyla işlenebilir. Kişisel verilerin korunmasına ilişkin esas ve usuller kanunla düzenlenir" hükmü eklenir. 2016 yılında yürürlüğe giren 6698 sayılı Kişisel Verilerin Korunması Kanunu m. 3/d fıkrasında kişisel veri, "kimliği belirli veya belirlenebilir gerçek kişiye ilişkin her türlü bilgi" şeklinde tanımlanır. Adı geçen Kanun ile Anayasal düzenlemede, gerçek kişi (natural person), kişisel veri (personal data) ve veri sahibi (data subject) kavramları 2018 yılında Avrupa Birliğinde yürürlüğe giren General Data Protection Regulation (GDPR-Genel Veri Koruma Tüzügü) ile paralel bir şekilde tanımlanır. GDPR m. 4/1'e göre 'kişisel veri', tanımlanmış veya tanımlanabilir bir gerçek kişiye ilişkin her türlü bilgidir ('veri sahibi'); tanımlanmış bir gerçek kişi özellikle bir isim, kimlik numarası, konum verileri, çevrim içi tanımlayıcı ya da söz konusu gerçek kişinin fiziksel, fizyolojik, genetik, ruhsal, ekonomik, kültürel veya toplumsal kimliğine özgü bir ya da daha fazla sayıda faktöre atıfta bulunularak doğrudan veya dolaylı olarak tanımlanabilen bir kişidir." vi

Öncelikle yukarıdaki pozitif hukuk normlarının 'gerçek kişi' (persona) kavramına yüklediği anlama değinelim. Hukukun hak bahşedip ödev yüklediği persona, insanın maddi ve 
manevi varlığıdır. İnsanın zaman ve mekân içinde yer tutan bedeni (maddi) ile soyut (manevi) aidiyetleri gerçek kişinin karşılığıdır. Hukuk kişisel veri ile gerçek kişi ilişkisini, insana ait belirli kimlik kategorileri ya da kişilik vasıflarıyla anlamlandırır. Medeni Kanun m. 8'e göre tam ve sağ doğumla başlayan haklara sahip olma ehliyeti, insanın hukuki kişilik kazanma anına tekabül eder. Hukuki kişilik statüsü, insanın bedensel bütünlüğünü, bedensel parçaları üzerindeki haklarını ve değer yaratma potansiyelini (manevi varlığını) korumayı vaat eder (Işıktaç, 2014, s. 52-57; Koloş, 2014, s. 121-129). Hukuk hak ehliyetine sahip insanın 'doğal' bir kişiliği, korunmaya değer maddi ve manevi varlığı olduğunu kayıt altına alır. Gerçek kişi, Medeni Kanun m. 9'a göre, fiilen hak sahibi olma ve borç altına girme ehliyeti kazandığında hukuki bir 'özne' haline gelir; eyleyen ve bilen kişi olur.

Hukuki özne, kişilik hakkını insan olması sıfatıyla doğuştan kazanır. Medeni Kanun m. 23'e göre, "kimse, hak ve fiil ehliyetlerinden kısmen de olsa vazgeçemez." Hukukun, insanın kişilik hakkının vazgeçilmezliğini normatif bir ilke kabul etmesinin arkasında, insan merkezci hümanist felsefenin homo universalis ideali -ya da ideolojisi- vardır; insan onurunun dokunulmazlığı ve üstünlüğü. İnsan merkezci hümanist felsefenin hukuki izdüşümü, kişilik hakkını, bir tür evrensel "ahlakilik" temelinde anlamlandırır. Bu nedenle modern hümanist hukuk, "onur", "özgürlük" ve "eşitlik" şeklinde tanımlanan ahlaki iyinin ve eylemin taşıyıcısı insana imtiyazı ıir konum ve koruma bahşetmiştir (Douzinas, 2017, s. 10 vd.). O halde kişisel verilerin korunması hakkı, gerçek kişinin (insanın) maddi/manevi varlığının (kişilik hakkının) 'insani' bir değeri temsil ettiği düşüncesine dayanır. Ne var ki öznelerin dijitalleştiği ileri kapitalizm koşullarında posthuman hukuk, kişisel verilerin korunmasının arkasında yatan bu düşünceyi -ya da ideolojiyi- terk eder ve insanın kişilik hakkını metalaştııı. Açıklayalım.

Kişisel verilerin korunmasına ilişkin hukuki normlar, gerçek kişi (doğal insan) ile belirli ya da belirlenebilir kişi (dijital insan) arasında bir ayrım tesis etmektedir aslında. Nitekim dijital ortamda paylaşılan bir verinin belirli ya da belirlenebilir gerçek kişiye isnat edilmesi ile gerçek kişiye (insana) kişisel bir verinin isnat edilmesi arasında belirgin bir fark vardır. İlkinde dijital bir platform, veri ile gerçek kişi arasına girer. Hukuk, dijital alandaki veriye dayanarak, belirli ya da belirlenebilir bir gerçek kişi; "dijital bir kişilik" tasarlar. Diğer deyişle, veri ile gerçek kişi arasında illiyet bağı kurma süreci "dijital kişilik" tasarısına dayanır. İkinci durumda hukuk, gerçek kişiye (insana) ait bir veriyi zaten ve çoktan kişilik hakkı bağlamında tanımıştır. Sözgelimi insanın özel adı üzerindeki hakkı bir kişilik hakkıdır. Insanın bedensel/zihinsel maddi/manevi- varlığını kimliklendiren kişisel bir veridir. Hukuk, insanın adı üzerindeki hakkını 
önceden tanıyarak tescil eder. Oysa bu veri kişinin rızası hilafına dijital bir ortamda görüldüğünde, hukuk, özel ad (veri) ile gerçek kişi arasında yeniden bir illiyet bağı kurmalıdır. Bir bakıma hukuk, illiyet bağı kurma aşamasında, insanın tanıdığı ve tescil ettiği kişilik hakkını koruyabilmek için, belirli ya da belirlenebilir bir "dijital kişi" varsayar. Tam da burada posthuman hukukun, insanın kişilik hakkına bir meta değeri biçtiğini, insanı ürünleştirdiğini ileri sürebiliriz. Dijital platformdaki veri ile gerçek kişi arasında kurulan her illiyet bağı, insanın kişilik unsurlarını eşya niteliğinde değerlendirir. Başka deyişle, insanın kişilik hakkı mübadele edilebilir bir "şey"dir artık. Hukuk kişilik hakkını korunduğunu iddia ederken, insanın kişilik/kimlik unsurlarını, doğuştan kazanılan bir yetkiye göre değil piyasa değerine göre ölçüp tartar. Örnekle devam edelim.

2014 yılında Google Spain davasında Avrupa Adalet Divanı, Mario Costeja González'in, Google Arama Motorunda adını arattığında 16 yı önceki sosyal güvenlik borçlarının tahsiline ilişkin haciz davalarıyla bağlantılı gayrimenkul açık artırma ilanını içeren bir günlük gazetenin internet üzerindeki arşivlerinde yer alan linklerin kaldırılması talebini kabul eder. Adalet Divanına göre, dijital ortamda özel adın -González-, olgusal bilgiyle -açık arttırmailişkilendirilerek kamuoyuna sunulması Avrupa Birliği Temel Haklar Şartının özel hayata ve aile hayatına saygı (m. 7) ile kişisel verilerin korunması (m. 8) hakkına aykırıdır. Başvuranın talebinin kabul edilmesinin üç gerekçesi vardır: (1) Dijital platformdaki veri -kişi ile ilgili bilginin liste aracılığıyla gerçek kişiye bağlanması- doğru olsa bile, güncelliğini yitirmiştir, zira üzerinden 16 yıl geçmiştir. (2) Kamuoyunun -olayımızda İspanya- bu veriye erişiminde üstün bir yararı yoktur. (3) Somut olayda, arama motoru operatörünün -Google- ekonomik menfaati, kişisel verinin silinmesi hakkından daha üstün değildir. ${ }^{\text {vii }}$

Lindroos-Hovinheimo, Ranciére'in eşitlik ve öznellikle ilgili argümanlarını yukarıdaki dava bağlamında tartısır. Lindroos-Hovinheimo göre (2016, s. 294) Adalet Divanı, verilerinin silinmesini talep eden gerçek kişinin (González) konuşma ve hak arama özgürlüğünü tanıyarak hukuki öznelliğini tescil etmiştir. Fakat öte yandan bu karar, hukukun varsayıp tanıdığı bir hukuki öznelliği üretir de. İnternette verilerinin silinmesini isteyen González'in hukuki mücadelesi "gönüllü bir görünmezlik vasıtasıyla özerklik arayışı" şeklinde anlaşılmalıdır. Internette kendisine ait bilginin kaldırılması için hukuki yollara başvurarak bir şirketi karşına alan gerçek kişi ("gönüllü bir görünmezlik"), kendisine dijital dünyada gelecekte var olmama hakkı tanınmasını (“özerklik arayışı”) talep etmektedir. Oysa González'in insanlığına -kişiliğinesıkı biçimde bağlı haklarını hukuk zaten ve çoktan tanımıştır. Kişilik/kimlik unsurları tanınan ve 
korunan gerçek kişi, özel adının arama motorunda yazıımasıyla görünen sonuçların silinmesini isteyerek, "kimliksizleşme"yi ya da "kimliğinin reddi"ni talep etmektedir (s. 298). Hukuk terminolojisiyle söylersek González, kişilik hakkının vermiş olduğu yetkiye dayanarak (gerçek kişi) dijital alandaki adı üzerindeki hakkından (dijital kişi) feragat etmek istemektedir. González, kişilik hakkına sahip bir hukuk öznesi olarak, dijital platformda maddi/manevi varlığına ait 'insani' bir değerin -kişilik/kimlik unsuru özel adın- varolmasını istemez. Hukuk, González'in unutulma hakkını tanıdığında; dijital ortamda kişilik hakkının bir parçasından -özel advazgeçmesini onayladığında, yeni bir hukuk öznesi üretmiş olur: İnternette görülen, belirli ya belirlenebilir gerçek kişiye ait özel bir adın taşıyıcısı dijital özne.

Hukukun tasarladığı bu dijital özne -veya dijital kişilik-, gerçek kişiye isnat edilen dijital ortamdaki pek çok verinin, insan kimliğine ait unsurları parçalaması ve yeniden cisimleştirmesiyle oluşur. Käll, belirli ya da belirlenebilen kişi nosyonunun, insanı söküp yeniden monte etmeye, her bir parçasına fikri mülkiyet değeri biçmeye yarayan bir "maske" olduğunu ileri sürer (2017, s. 1156). Başka bir ifadeyle hukuk, veri ile gerçek kişi arasında kurduğu illiyet bağı vasıtasıyla maske formunda bir dijital kişilik tasarlar. viii Käll'e göre hukuk, maske formundaki belirli ya da belirlenebilir bu dijital kişiliğin insanla (bedenle) bağlantısını keser ve insanın kişilik hakkına ekonomik bir değer atfeder. Yukarıdaki hukuki uyuşmazlıkta Adalet Divanı, Google'ın ekonomik menfaatinin kişinin unutulma hakkından daha üstün olmadığına karar vermişti. Tersinden argümanlaştıralım: Bir piyasa aktörünün ekonomik menfaatinin daha üstün olduğu durumda, gerçek kişinin unutulma hakkının hiçbir anlamı yoktur (s. 1154). Käll'in işaret ettiği gibi, posthuman hukuk, (1) kişilik hakkını şirketin ekonomik çıkarıyla denkleştirerek, (2) insanın bedenini ve haklarını piyasada mübadele edilebilir bir meta ya da ürün haline getirmiştir. ${ }^{\text {ix }}$

Braidotti'nin posthuman kadın-oluşu kuluçka makinesiyle özdeşleştirmesi gibi, hukuk da insanın kişilik statüsünü, eşya değerine indirgeyerek ekonomik menfaatin tarafı kılar: Google versus Mario Costeja González. Ileri kapitalizmde, ekonomik menfaatin bir tarafında Google diğer tarafında insanın meta değerindeki kişilik hakkı vardır. Posthuman hukuk, teknolojik ağ ve aygıtların maliki bir şirketin ekonomik çıkarı ile Mario Costeja González'in kişilik hakkını aynı terazide tartarak, modern hümanist hukukun normatif ilkelerle tasarladığı insan portresini siler. Bundan böyle insanın kişilik hakkının normatif bir değeri yoktur. Posthuman hukuk, dijital öznenin maddi/manevi varlığı üzerindeki haklarının anlamını piyasa değerine göre belirler. Posthuman hukuk açısından dijital öznenin kişilik hakkının insani değeri, meta değeriyle yer 
değiştirmiştir. Nitekim şirketin ekonomik menfaati daha üstün olmadığı sürece insanın kişilik hakkı veya kimliğinin asli bileşenleri -özel ad-, hukuken korunmaya değerdir.

Hatırlatmakta fayda var: Illeri kapitalizmin şimdisinde tecrübe ettiğimiz dijitalleşme çağında, posthuman hukukun dijital öznelerin kişilik hakkını metalaştırdığını ileri sürerken, hümanist felsefenin insan tasarımına kurtarıcı bir rol atfetmiyorum. Nihayetinde modern hukukun homo universalis idealine tutunması ya da insanın kişilik hakkına "evrensel ahlakilik" ilkesine dayanarak ayrıcalıklı bir konum bahşetmesi, insan merkezci hümanist felsefenin bir görünümüdür. Aksine, insani dilini ve ruhunu kaybetmiş -tekno-bilim insanı Lester gibiteknoloji dolayımındaki insan sonrası insanın -dijital öznelerin- bedenleri ve haklarının hukukun gözünde de değer kaybına uğradığını göstermeye çalışıyorum. İnsan sonrasının dijital öznesi, teknolojinin normatif açıdan nötr olduğunu ileri süren Braidotti'nin düşüncesiyle uyumlu bir şekilde, normatif değerinden yalıtılmış, eşya ile aynı kategoride ölçüp biçilen bir veri ya da ürün haline gelmiştir. Hâlihazırdaki ileri kapitalizm koşullarında posthuman hukukun muhatabı dijital öznedir ve dijital öznenin insanlığı ürüne, kişilik hakkı metaya dönüşmüştür.

\section{Sonuç}

Braidotti'ye göre, farklılıkları nedeniyle akıl-dışı, ahlak-dışı hatta insanlık-dışı addedilen ötekiler ile bilim ve teknolojinin ürettiği makine-oluş sürecindeki başkaları, insan sonrası öznellik formlarıdır. Braidotti, bu posthuman öznellik formlarının klasik erkek insan figürü aleyhine "yaratıcı bir alternatif" oluşturduğunu ileri sürer. Braidotti'nin alternatif yaşam modeli, teknobilimsel aygıtların değiştirip dönüştürdüğü insanın, kadim ötekiler ve yeni başkalarıyla hep birlikte, etik ilişkiler tesis edebilecekleri bir ikinci doğa tasarısıdır.

Ne var ki tam da alternatif yaşam modelini mümkün kılan ileri kapitalizm, yarattığı her şeyi gözetleyerek, deforme ederek sosyo-ekonomik eşitsizliği yeniden üretir. Illeri kapitalizmin her an her şeyi denetleyerek şekillendirdiği günümüzde, yaşamsal ve insani değerler, "ultrahızlı" biçimde tükenmekte, tüketilmektedir. Bu tür bir gerçeklikte Braidotti'nin projesi, iyimser bir varsayımdan; barış̧̧ı bir doğa hali kurgusundan öteye geçemez. Öyle ki Braidotti'nin etik ve eşit ilişkilerin boy göstereceğine inandığı insan sonrası tasarısı, dijital öznelerin yaşadığı ileri kapitalizm koşullarında, insanlık-dışı bir hiyerarşiyi, gönül dilinden -yaşam değerinden- yoksun bir ilişkiselliği kaldığı yerden devam ettirir. 
Posthuman hukuk, oluş ufkunda mütemadiyen dönüşen günümüz insan sonrası dijital öznelerin insanlığına eşya değeri biçmektedir. Dijital öznenin çevrimiçi ağlarda cisimleşen varlığının ne hukuken ne ahlaken kişilik değeri vardır. Posthuman hukukun hak sahibi öznesi, insani kişiliğini/kimliğini kaybetmiş bir meta, piyasada mübadele edilebilir bir üründür.

\section{ORCID ID}

RABIA SAĞLAM

(iD) https://orcid.org/0000-0002-3774-4332

\section{Declaration of Conflicting Interests}

The author declared that there were no conflicts of interest with respect to the authorship or the publication of this article.

\section{Çıkar Çatışması Beyanı}

Yazar bu makalenin yazarlık veya yayımlanmasına ilişkin olarak hiçbir çıkar çatışması olmadığını beyan etmiştir.

\section{KAYNAKÇA}

Braidotti, R. (2017). Göçebe Özneler, Çağdaş Feminist Kuramda Bedenleşme ve Cinsiyet Farklıı̆̆ı. (Öznur Karakaş, Çev.) İstanbul: Kolektif.

Braidotti, R. (2018). Insan Sonrası. (Öznur Karakaş, Çev.) İstanbul: Kolektif.

Braidotti, R. (2013). "Posthuman Humanities", European Educational Research Journal, 12 (1), 1-19.

Braidotti, R. (2019a). Kadın-Oluş: Cinsel Farkı Yeniden Düşünmek. (Münevver Çelik, Çev.) İstanbul: Otonom.

Braidotti, R. (2019b). "Insan Sonrası, Pek İnsanca: Bir Posthümanistin Anıları ve Emelleri" (Bülent O. Doğan, Çev.), Cogito Insan Sonrası, Sayı: 95-96, 53-97.

Corda, R. (2017). "The Force Of The Affections: The Becoming-body, The Becoming-free", Posthuman: Consciousness and Pathic Engagement. (Paolo Augusto Masullo, Mauro Maldonato, Ed.), Sussex Academic Press, 85-112.

Çelik, E. E. (2019). "Antroposen ve Posthuman İnsan Çağı'nda İnsan Sonrası Olmak”, Cogito Insan Sonrası, Sayı: 95-96, 145-160.

Deleuze, G. (1992). "Postscript on the Societies of Control”, October, (Winter 59), 3-7. 
Dick, P. K. (1955). “Human Is", Startling Stories, A Thrilling Publication, 32 (3), 67-74.

Douzinas, C. (2017). Insan Hakları ve Imparatorluk Kozmopolitanizmin Siyasal Felsefesi. (Kasım Akbaş-Rabia Sağlam, Çev.) İstanbul: Bilgi Üniversitesi Yayınları.

Ferrando, F. (2013). "Posthumanism, Transhumanism, Antihumanism, Metahumanizm and New Materialisms Differences and Relations", Existenz, 8 (2), 26-32.

Haraway, D. (2006). Siborg Manifestosu, Geç Yirminci Yüzyılda Bilim, Teknoloji ve SosyalistFeminizm. (Osman Akınhay, Çev.) İstanbul: Agora Kitaplığı.

Hayles, N. K. (1999). How We Became Posthuman, Virtual Bodies in Cybernetics, Literature And Informatics. Chicago- London: The University Of Chicago Press.

Işıktaç, Y. (2014). "Insanın Bedeni Üzerindeki Hakları", Dönüşen Toplum-Dönüşen Hukuk I Metamorfoz. (Yasemin Işıktaç, Ed.) İstanbul: Sümer Kitapevi, 41-72.

Käll, J. (2017). "A Posthuman Data Subject? The Right to Be Forgotten and Beyond", German Law Journal, 18(5), 1145-1162.

Koloş, U. (2014). "Mikro-iktidar Iliş̧kileri ve Hukuk Öznesinin Teşekkülü”, Dönüşen ToplumDönüşen Hukuk I Metamorfoz. (Yasemin Işıktaç, Ed.) İstanbul: Sümer Kitapevi, 73-141.

Lindroos-Hovinheimo, S. (2016). "Legal Subjectivity and the 'Right to be Forgotten': Ranciérean Analysis of Google", Law and Critique, 27 (3), 289-301.

Miah, A. (2007). "A Critical History of Posthumanism", Medical Enhancements \& Posthumanity. (Gordijn B. \& Chadwick, R., Ed.) New York: Routledge, 1-29.

Numanoğlu, Ö. (2018). “Osmanlı'nın Vampir Fetvaları”, Güncel Hukuk Dergisi, Sayı: 174, 8-9. O’Neil, C. (2020). Matematiksel Imha Silahları. (Akın Emre Pilgir, Çev.) İstanbul: Tellekt.

Postma, F. (2019). Military Drones and the EU. (Susan Clark, Ed.). https://www.paxforpeace.nl/publications/all-publications/military-drones-and-the-eu, Erişim Tarihi: 20.10.2020.

Sağlam, R. (2020). "Yapıbozumcu Kimlik Okuması: Spivak ve Madun Kadının Kolektif Özne Statüsü”, Hukuk Kuramı, 7 (1-2), 1-27.

Scheler, M. (2015). Hınç. (Abdullah Yılmaz, Çev.) İstanbul: Alfa.

Wennemann, D. J. (2016). "The Concept of the Posthuman: Chain of Being or Conceptual Saltus?", Journal of Evolution and Technology, 26 (2), 16-30.

Zizek, S. (2013). Bedensiz Organlar. (Umut Yener Kara, Çev.) İstanbul: MonoKL. 


\section{Sonnotlar}

'https://www.lexico.com/definition/posthumanism, Erişim Tarihi: 20.10.2020.

ii Braidotti'nin görüşleri ve metinlerinin farklı bir okuması için bkz.: Çelik, E. E. (2019). "Antroposen ve Posthuman İnsan Çağı'nda İnsan Sonrası Olmak”, Cogito İnsan Sonrası, Sayı: 95-96, 145-160.

iii https://www.gsd.harvard.edu/event/rosi-braidotti/, Erişim Tarihi: 07.07.2020.

iv Öykünün dizi-film uyarlaması için bkz. Electric Dreams, Human Is, Episode 6, 2017.

` Lester, yeğen Gus'ın oyuncak kedisini kaplan sanmasını yadırgar. Lester'a göre çocuklar, ilizyonlarından ya da saçmalıklardan kurtulup gerçekçi olmalıdır. Lester’ın gerçekçilikten anladığı tekno-bilimsel düşünme ve eyleme sürecine uyum sağlamaktır. Bu yüzden çocuğu teknolojinin ve bilimin zuhur ettiği mekanik dünyaya davet eder: "Arada laboratuvara gelsene, araştırmalarda kullandığımız bir sürü kedi, kobay domuz, tavşan görürsün” (Dick, 1955, s. 68).

vi https://www.kisiselverilerinkorunmasi.org/wp-content/uploads/2017/09/GDPR-Türkçe-Çeviri-AB-Bakanlığı. Erişim Tarihi: 10.01.2021.

vii https://abgm.adalet.gov.tr/abadaletdivani/belgeler/karar_13.pdf ABAD- C-131/12 Karar (Google Spain SL ve Diğer Şirket / Agencia Espanola De Proteccion De Datos (AEPD) ve Diğeri. Erişim Tarihi: 10.01.2021.

viii Latince persona kavramının “aktörün oynadığı karakter, maske” anlamına geldiğini not edelim.

ix Käll, J. (2017). "Converging Human and Digital Bodies, Posthumanism, Property, Law" https://www.academia.edu/33158972/Doctoral Thesis in Legal Theory Converging Human and Digital Bodi es Posthumanism Property Law. Erişim Tarihi: 10.01.2021. 